\title{
PENINGKATAN KEMAMPUAN APRESIASI DRAMA MATERI PERISTIWA SEKITAR PROKLAMASI MELALUI PENERAPAN METODE BERMAIN PERAN (ROLE PLAYING) PADA SISWA KELAS XI IIS-1 SMA NEGERI 1 NGIMBANG LAMONGAN
}

\author{
Luluk Hermiwati \\ luluk_66@gmail.com \\ SMA Negeri 1 Ngimbang
}

\begin{abstract}
Abstrak
Penelitian tindakan kelas ini memiliki tujuan untuk meningkatkan apresiasi drama materi sekitar proklamasi dengan menggunakan metode bermain peran (Role Playing) pada pokok bahasan drama pendek yang dilakukan di kelas XI IIS-1 SMA Negeri 1 Ngimbang tahun pelajaran 2017/2018 dan melihat bagaimana peningkatan kemampuan siswa dalam mengapresiasi drama. Pada Penilitian Tindakan Kelas ini peneliti mengambil populasinya yakni kelas tinggi $(4,5,6)$ pada SMA Negeri 1 Ngimbang akan tetapi yang menjadi sampel penelitian ini pada kelas XI IIS-1 yang berjumlah 32 siswa. Untuk mendapatkan hasil yang baik dan untuk mengetahui perkembangan kemampuan anak maka peneliti melakukan tindakan sebanyak dua siklus. Pada siklus I dan siklus II ternyata mengalami peningkatan kemampuan apresiasi drama materi sekitar proklamasi kearah yang lebih baik walaupun tidak secara signifikan, ini menunjukkan bahwa penelitian dengan menggunakan metode bermain peran ini harus lebih ditingkatkan lagi. Dari hasil perhitungan berdasarkan skor yang diperoleh pada siklus I yaitu 66,02 dan mengalami peningkatan menjadi rata-rata 70,25 pada siklus II. Dari data-data hasil penelitian tersebut maka dapat diambil kesimpulan bahwa pembelajaran menggunakan metode bermain peran ini dapat meningkatkan apresiasi drama pendek materi sekitar proklamasi pada anak-anak kelas XI IIS-1. Hasil positif ini ditunjukkan dengan mulai meningkatnya rasa kepercayaan diri anak dalam memerankan tokoh sesuai dengan karakter yang diinginkan seperti dalam teks drama pendek tersebut. Dengan mulai meningkatnya rasa percaya diri ini memberi efek positif dan merupakan modal dalam mengembangkan apresiasi terhadap drama pendek pada materi sekitar proklamasi.
\end{abstract}

Kata kunci: Metode Bermain Peran (Role Playing)

\section{PENDAHULUAN}

\begin{tabular}{lllr} 
& Pengajaran & \multicolumn{2}{c}{ Sejarah mempunyai } \\
ruang lingkup & dan tujuan yang \\
menumbuhkan & kemampuan & yang
\end{tabular}
mengungkapkan pikiran dan perasaan dengan mengguankan bahasa yang baik dan benar. Pada hakikatnya pembelajaran Sejarah diarahkan untuk mempertajam kepekaan perasaan siswa. Guru dituntut mampu memotivasi siswa agar mereka dapat meningkatkan minat baca terhadap karya sastra, karena dengan mempelajari sastra siswa diharapkan dapat menarik berbagai manfaat dari kehidupannya.

Seorang guru harus dapat mengarahkan siswa memiliki karya sastra yang sesuai dengan minat dan kematangan jiwa mereka. Berbagai upaya latihan dapat dilakukan salah satunya dengan memberikan tugas untuk membuat karya sastra yaitu permainan drama pendek sederhana. Keterampilan apresiasi drama perlu ditanamkan kepada siswa sekolah dasar, sehingga mereka mempunyai kemampuan untuk mengapresiasikan drama dengan baik. Mengapresiasikan sebuah drama bukan hanya ditujukan untuk penghayatan dan pemahan drama, melainkan berpengaruh mempertajam terhadap kepekaan perasaan, penalaran, serta kepekaan jiwa anak terhadap masalah kemanusiaan. Kemampuan tersebut ditentukan oleh beberapa factor penting dalam proses pembelajaran apresiasi drama. Selain pelatihan menghayati peran masingmasing, pemilihan naskah yang sesuai dengan jiwa masa anak-anak, juga yang sangat menentukan adalah peranan 
guru dalam proses pembelajaran terhadap siswa

Berdasarkan pengamatan awal yang dilakukan, penulis menemukan beberapa permasalahan mendasar yang menyebabkan rendahnya kemampuan apresiasi drama dalam Pelajaran Sejarah di kelas XI IIS-1 SMA Negeri 1 Ngimbang. Permasalahan tersebut dapat diuraikan antara lain, yang pertama yaitu sebagian besar siswa kelas XI IIS-1 kesulitan dalam membuat drama pendek dengan bahasanya sendiri maupun gagasannya sendiri. Dalam kejadian ini guru langsung memberikan contoh drama dan menyuruh siswa untuk membaca contoh drama tersebut, tanpa memberi kesempatan pada siswa untuk membuat drama dengan bahasannya sendiri ataupun dengan gagasannya sendiri. Permasalahan kedua, siswa kesulitan menentukan tema sebuah drama. Permasalahan yang ketiga siswa SMA Negeri 1 Ngimbang kesulitan menentukan kosakata untuk dituangkan kedalam sebuah drama yang ingin mereka tulis.

Melihat dari kondisi tersebut, akhirnya penulis mempunyai ide untuk memperbaiki pembelajaran tersebut dengan menerapkan teknik bermain peran dalam upaya meningkatkan kemampuan apresiasi drama di kelas XI IIS-1 SMA Negeri 1 Ngimbang. Bermain bagi anakanak tidak ubahnya seperti bekerja bagi orang dewasa. Bermain merupakan kegiatan yang menimbulkan kenikmatan yang akan menjadi rangsangan bagi perilaku lainnnya. Waktu bagi anak-anak yang sedang bermain tidak jauh berbeda dengan waktu untuk bekerjanya orang dewasa. Usia siswa sekolah dasar merupakan usia yang paling kreatif dalam hidup manusia. Anak-anak merupakan makhluk yang unik sehingga dalam pembelajaran mereka tidak harus merasa terpenjara.

Menurut (Charlotte Buhler dalam (Sugianto), 1997:105), bermain merupakan sarana untuk mengubah potensi-potensi yang ada dalam dirinya.
Berdasarkan beberapa alasan dan pendapat di atas maka penulis mencoba melakukan penelitian tindakan kelas dengan mengambil judul "Peningkatan kemampuan apresiasi drama melalui penerapan metode bermain peran (Role Playing) pada siswa kelas XI IIS-1 SMA Negeri 1 Ngimbang".

Berdasarkan judul di atas penulis akan melakukan penelitian tindakan kelas yang diharapkan dapat meningkatkan kemampuan anak didik dalam mengapresiasi sastra pada umumnya dan mampu mengapresiasi drama pada khusunya yang berkaitan dengan peristiwa-peristiwa sejarah di Indonesia.

\section{METODE}

Penelitian ini menggunakan metode Penelitian Tindakan Kelas (PTK) atau ditulis dalam Bahasa Inggris denagn istilah Clasroom Action Research (CAR) yang dikembangkan oleh John Elliot dan menggunakan desain pelksanaan PTK yang diadaptasi dari Hopkins. Tujuan Penelitian Tindakan Kelas yakni melihat kembali, mengkaji secara seksama dan menyempurnakan kegiatan pembelajaran yang telah dilaksanakan serta memperbaiki proses pembelajaran yang kurang berhasil.

Penelitian ini dilakukan untuk melihat aktivitas siswa sekaligus melihat gambaran tentang peranan bermain peran untuk meningkatkan kemampuan apresiasi drama dalam pelajaran Sejarah di kelas XI IIS-1 SMA Negeri 1 Ngimbang Lamongan. Penelitian ini bertujuan untuk mengkaji suatu permasalahan, yaitu kurang aktifnya siswa selama kegiaan belajar mengajar Sejarah sehingga mereka masih sangat bergantung pada apa yang diberikan oleh guru. Penelitian ini dilaksanakan sebanyak 2 siklus. Sebelum masuk pada siklus I dilakukan tindakan pendahuluan yang berupa identifikasi permasalahan. Observasi dilakukan pada tiap siklus, dan melakukan kegiatan pembelajaran berdasarkan kompetensi dasar yang ingin 
dicapai. Proses pembelajaran pada masing-masing siklus dikenai perlakuan yang sama (langkah-langkah kegiatan yang sama), dimana perlakuan dalam setiap putaran (siklus) terdiri dari empat komponen pokok yaitu perencanaan, tindakan, observasi dan refleksi.

Sasaran penelitian ini adalah semua siswa kelas XI IIS-1 SMA Negeri 1 Ngimbang tahun pelajaran 2017/2018 yang berjumlah 32 orang yang terdiri dari 15 orang laki-laki dan 17 orang perempuan.

Instrumen yang digunakan dalam penelitian ini terdiri dari Rencana Pelaksanaan Pembelajaran (RPP), Lembar Observasi, Lembar Kerja Siswa, lembar penilaian, lembar wawancara dan alat-alat pendukung lainnya.

Metode pengumpulan data penelitian ini adalah (1) metode observasi terhadap pengelolaan pembelajaran dengan metode Role Playing, observasi aktivitas siswa dan guru (2) metode tes, digunakan untuk mengetahui ketuntasan hasil belajar siswa dalam kegiatan belajar mengajar berlangsung dalam pembelajaran dengan metode Role Playing pada materi sekitar proklamasi. Tes dilakukan pada setiap pertemuan setelah kegiatan belajar mengajar berakhir, (3) metode wawancara, yaitu teknik pengumpulan informasi melalui komunikasi secara langsung dengan responden. Teknik wawancara dilakukan sebagai upaya untuk memperoleh data tentang pendapat siswa mengenai proses belajar.

Penelitian ini menggunakan teknik analisis data sebagai berikut : data-data dalam penelitian ini dikumpulkan kemudian diolah dan dianalisis. Pengolahan dan analisis data ini dilakukan selama berlangsungnya penelitian sejak awal sampai akhir pelaksanaan tindakan. Teknik analisis data yang digunakan yaitu bersifat kuantitatif dan kualitatif. Prosedur analisis dari tiap data yang diperoleh dari penelitian ini adalah sebagai berikut:

(1) Analisis Data Keterlaksanaan Metode Role Playing

Data kuantitatif berasal dari tes siklus untuk menguji kemampuan anak dalam mengapresiasi drama setelah data kualitatif diperoleh, selanjutnya dilakukan langkahlangkah analisis sebagai berikut:

a. Penskoran terhadap kemampuan siswa dalam mengapresiasi drama.

b. Persentase tingkat keberhasilan berdasarkan skor yang diperoleh dicari dengan menggunakan rumus.

Untuk mengklarifikasi kualitas kemampuan siswa, maka data hasil tes dikelompokkan dengan menggunakan skala lima (Suherman dan kusumah, 1990:272 dalam Sufyani P), yaitu sebagai berikut:

Tabel 1. Kriteria Penentuan Tingkat Kemampuan Siswa

\begin{tabular}{cc}
\hline $\begin{array}{c}\text { Persentase Skor } \\
\text { Total Siswa }\end{array}$ & $\begin{array}{c}\text { Kategori } \\
\text { Kemampuan Siswa }\end{array}$ \\
$90 \%<\mathrm{A} \leq 100 \%$ & $\mathrm{~A}$ (Sangat Baik) \\
$75 \%<\mathrm{B} \leq 90 \%$ & $\mathrm{~B}$ (Baik) \\
$55 \%<\mathrm{C} \leq 75 \%$ & $\mathrm{C}$ (Cukup) \\
$40 \%<\mathrm{D} \leq 55 \%$ & $\mathrm{D}$ (Kurang) \\
$0 \%<\mathrm{E} \leq 40 \%$ & $\mathrm{E}$ (Buruk) \\
\hline
\end{tabular}

(2) Analisis Data Tes Hasil Belajar Siswa

Untuk mengetahui masingmasing ketuntasan belajar siswa. Secara individual siswa tuntas belajar jika mencapai daya serap 75\% keatas Perhitungan persentase ketuntasan siswa secara individual yaitu:

Nilai $=\underline{\text { Jumlah Skor yang diperoleh }} \times$ skala (100) Jumlah Skor Maksimum

Sedangkan secara klasikal suatu kelas telah tuntas belajar jika $85 \%$ 
siswa telah mencapai daya serap $75 \%$ keatas dengan perhitungan:

Ketuntasan Klasikal $=$ Jumlah siswa yang tuntas $\times 100 \%$ Jumlah seluruh siswa

\section{PEMBAHASAN}

\section{Kondisi Belajar Siswa}

Pada fase pra tindakan (sebelum penerapan metode ROLE PLAYING dilakukan), perhatian siswa tidak terfokus pada pembelajaran, terutama pada saat guru menyampaikan materi, di samping itu juga sebagian besar siswa kurang antusias dalam mengikuti kegiatan pembelajaran.

Pada siklus I, sebagian besar siswa sudah mulai antusias atau sudah mulai fokus mengikuti proses pembelajaran. Siswa sudah mau berlatih dengan sungguh-sungguh. Mereka merasa senang dengan sistem pembelajaran bermain peran ini. Namun ada beberapa siswa yang masih malu-malu dan terasa kaku untuk memainkan peran tokoh dalam drama pendek tersebut. Dalam hal ini guru bersikap sebagai pembimbing dan pengarah agara mereka termotivasi dan lebih aktif lagi dalam setiap pembelajaran selanjutnya.

Setelah selesai memberikan penjelasan maka guru menyuruh setiap kelompok tersebut untuk kembali tampil di depan kelas untuk bermain peran, yaitu memerankan tokoh yang ada dalam teks drama tersebut. Sementara kelompok lain menyimak dan memberi komentar terhadap kelompok lain yang tampil di depan kelas. Sehingga masing-masing kelompok dengan sendirinya juga mampu untuk mengoreksi kelemahan kelompok masing-masing sekaligus mampu menutupi dan memperbaiki kelemahan tersebut. Hal tersebut menunjukkan penggunaan metode ROLE PLAYING dalam proses pembelajaran bisa diterima oleh sebagian besar siswa. Kondisi tersebut menunjukkan adanya perubahan yang lebih baik terhadap kondisi belajar siswa jika dibandingkan dengan kondisi belajar siswa pada pra tindakan.

Pada siklus II, hampir tidak ditemukan siswa yang bercanda dengan temannya selama proses pembelajaran berlangsung, bahkan sebagian besar siswa sudah mau berkonsultasi kepada guru atau kolaborator. Pada pertemuan pertama masih belajar tentang bermain peran untuk menumbuhkan rasa percaya diri dalam memerankan tokoh di depan kelas. Kegiatan selanjutnya guru mulai pada kegiatan penelitian tindakan siklus II dengan mulai melaksanakan apersepsi tentang kegiatan pembelajaran pada siklus II. Setelah siswa termotivasi dengan banyaknya respon yang disampaikan oleh siswa, kegiatan dilakukan dengan memberitahukan tujuan dari pembelajaran yang akan dilaksanakan pada kegiatan pembelajaran tindakan siklus II. Setting kelas pada pertemuan pertama sama seperti pada siklus I, siswa masih bekerja sesuai dengan kelompok yang telah dibagi dengan anggota tiap kelompok adalah 5-6 orang, dan terbagi menjadi 8 kelompok. Kegiatan selanjutnya adalah membagi teks drama yang kan dipelajari untuk kemudian tampil di depan kelas.

Setelah tenggang waktu yang disediakan siswa tampil ke depan kelas sementara kelompok lain memperhatikan dan memeberi penialaian terhadap masingmasing anak dalam memerankan tokoh yang diperankannya. Setelah melalui tahap latihan dalam memerankan tokoh dalam drama tersebut ternyata mengalalami peningkatan dibandingkan dengan siklus I. Kelompok yang pada mulanya mendapat nilai 61 menjadi 77 dan yang lainnya juga mangalami peningkatan. Siswa sudah memiliki kemampuan yang cukup meningkat sehingga bisa dijadikan dasar untuk pembelajaran selanjutnya dimana setiap anggota kelompok sudah memiliki kesadaran pentingnya bermain peran untuk meningkatkan kepercayaan diri pada umumnya dan meningkatkan kemampuan dalam apresiasi drama pada khususnya 
Hal tersebut menunjukkan bahwa kondisi belajar siswa mengalami peningkatan kearah yang lebih baik, atau dapat dikatakan bahwa kualitas proses pembelajaran pada siklus II lebih baik jika dibandingkan dengan proses pembelajaran pada siklus I.
Perkembangan kondisi belajar siswa pada fase pra tindakan, siklus I dan siklus II dapat digambarkan pada grafik berikut :

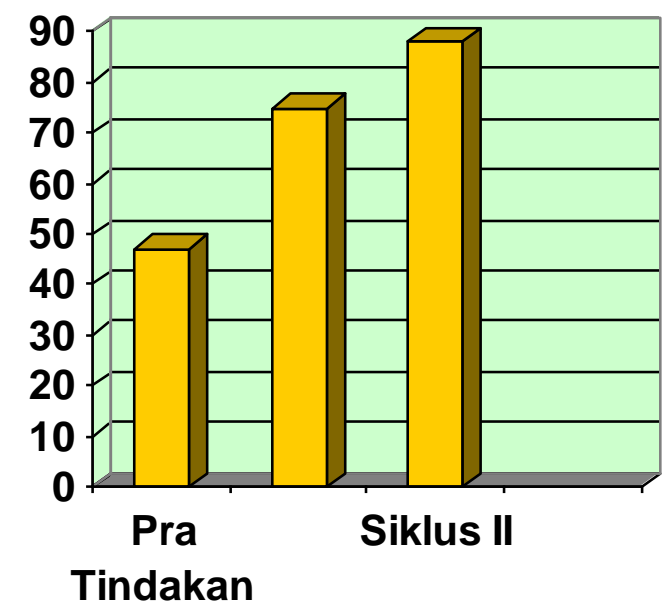

\section{Grafik 1. Tingkat Aktivitas Kelompok Belajar Siswa Hasil Pembelajaran Pra tindakan, Siklus I dan II}

\section{Hasil Belajar Siswa}

Hasil penilaian terhadap kemampuan siswa dalam bermain peran materi sekitar proklamasi melalui metode Role Playing pada siklus I adalah sebagai berikut :

\section{Rekapitulasi Nilai Tes Hasil Belajar} Siklus I

\begin{tabular}{clc}
\hline No. & \multicolumn{1}{c}{ Karakteristik } & Jumlah \\
1. & Jumlah siswa & 32 \\
2. & Rata-rata kelas & 71,78 \\
3. & Jumlah siswa yang & 18 \\
tuntas & Jumlah siswa yang & 14 \\
4. & $\begin{array}{l}\text { tidak tuntas } \\
\text { \% Ketuntasan } \\
\text { 5. }\end{array}$ & $50,63 \%$ \\
\hline
\end{tabular}

Berdasarkan tabel di atas dapat diketahui rata-rata nilai siswa adalah 71,78 dan jumlah siswa yang tuntas belajarnya sebanyak 18 orang siswa, sehingga masih terdapat 14 siswa yang tidak tuntas belajarnya. Hal ini disebabkan siswa belum terbiasa dengan penerapan pembelajaran dengan pendekatan ROLE PLAYING. Dari jumlah siswa yang tuntas belajarnya tersebut, maka didapatkan ketuntasan secara klasikal sebesar 50,63\%. Hasil yang diperoleh tersebut, jika ditinjau dari prestasi belajar siswa maka pembelajaran dengan pendekatan ROLE PLAYING pada materi sekitar proklamasi dapat dikatakan belum tuntas, karena hasil yang diperoleh masih dibawah standar yang ditetapkan yaitu ketuntasan belajar secara klasikal diperoleh apabila di dalam kelas tersebut terdapat $85 \%$ siswa yang tuntas belajar atau mendapat nilai $\geq 75$.

Selanjutnya, hasil penilaian terhadap kemampuan siswa dalam bermain peran materi sekitar proklamasi melalui 
metode Role Playing pada siklus II adalah sebagai berikut:

\begin{tabular}{clc}
\multicolumn{3}{c}{ Rekapitulasi Nilai Tes Hasil Belajar } \\
\multicolumn{3}{l}{ Siklus II } \\
\hline No. & Karakteristik & Jumlah \\
1. & Jumlah siswa & 32 \\
2. & $\begin{array}{l}\text { Rata-rata kelas } \\
\text { Jumlah siswa }\end{array}$ & 80,43 \\
3. & $\begin{array}{l}\text { yang tuntas } \\
\text { Jumlah siswa }\end{array}$ \\
4. & $\begin{array}{l}\text { yang tidak } \\
\text { tuntas }\end{array}$ \\
\% Ketuntasan & - \\
klasikal & $100 \%$ \\
\hline
\end{tabular}

Berdasarkan tabel 4.10 di atas dapat diketahui rata-rata nilai siswa dalam kelas adalah 80,43 dan jumlah siswa yang tuntas belajarnya sebanyak 32 orang siswa, sehingga sudah tidak ada siswa yang tidak tuntas belajarnya. Pencapaian hasil tersebut menunjukkan bahwa ketuntasan belajar secara klasikal sebesar $100 \%$. Hasil yang diperoleh tersebut, jika ditinjau dari prestasi belajar siswa maka pembelajaran melalui pembelajaran dengan pendekatan ROLE PLAYING pada materi sekitar proklamasi dapat dikatakan tuntas, karena hasil yang diperoleh di atas standar yang ditetapkan yaitu ketuntasan belajar secara klasikal diperoleh apabila di dalam kelas tersebut terdapat $85 \%$ siswa yang tuntas belajar atau mendapat nilai $\geq 75$.

Dari data-data yang telah diperoleh selama pelaksanaan tindakan siklus I dan siklus II pada proses pembelajaran melalui penerapan pendekatan ROLE PLAYING sebagaimana tersebut di atas, maka dapat diuraikan hal-hal sebagai berikut:

1) Berdasarkan data hasil pengamatan diketahui bahwa dalam mengikuti kegiatan pembelajaran penerapan pendekatan ROLE PLAYING, secara bertahap siswa mampu meningkatkan aktifitas dan kualitas belajarnya

2) Diperlukan adanya upaya perbaikan terhadap segala kekurangan pada siklus sebelumnya, sehingga pencapaian pada siklus berikutnya mengalami peningkatan.

3) Pencapaian hasil pada siklus II menunjukkan bahwa penerapan pendekatan ROLE PLAYING khususnya pada materi sekitar proklamasi dalam pembelajaran Sejarah dapat menciptakan keantusiasan dan keseriusan siswa dalam proses belajarnya sehingga berdampak positif bagi peningkatan hasil belajar siswa.

Perkembangan prestasi belajar siswa pada fase pra tindakan, siklus I dan siklus II dapat digambarkan pada grafik berikut : 


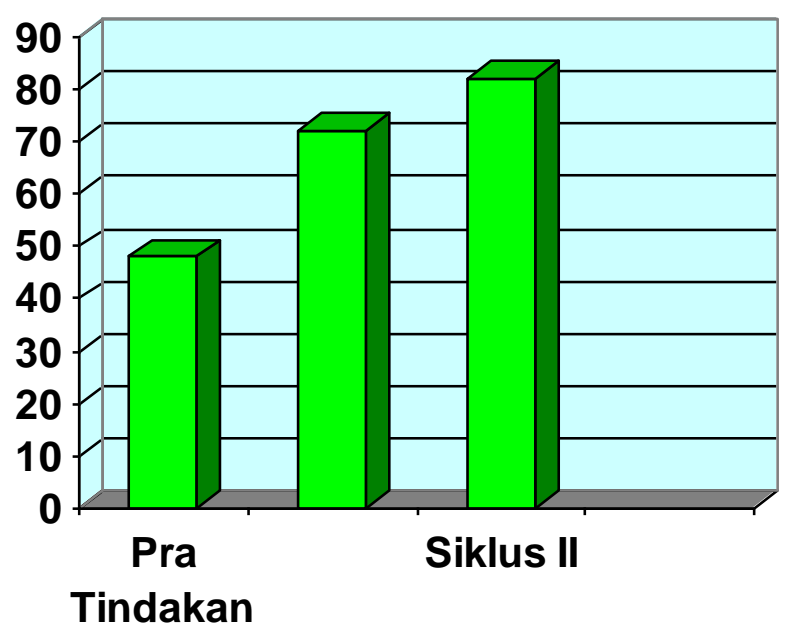

\section{Grafik 2. Tingkat Pencapaian Nilai Rata-rata Hasil Pembelajaran pada Fase Pra Tindakan, sikus I dan Siklus II}

\section{KESIMPULAN}

Dari hasil serangkaian analisis data dan pembahasannya, maka dapat diambil satu kesimpulan bahwa penerapan metode bermain peran (Role Playing) pada materi sekitar proklamasi dapat meningkatkan kemampuan apresiasi drama siswa kelas XI IIS-1 SMA Negeri 1 Ngimbang Lamongan.

\section{DAFTAR PUSTAKA}

Angkasa. Hamidy, U.U. 1984. Pengantar Kajian Drama. Pekanbaru: Bumi Pustaka.

Arikunto, Suharsimi. 2001. Dasar-dasar Evaluasi Pendidikan. Jakarta: Bumi Aksara.

Arikunto, Suharsimi. 2002. Prosedur Penelitian Suatu Pendekatan Praktek. Jakarta: Rineksa Cipta.

Azhar, Lalu Muhammad. 1993. Proses Belajar Mengajar Pendidikan. Jakarta: Usaha Nasional.

Brahim. 1968. Drama dalam Pendidikan. Jakarta: Gunung Agung.

Djamarah, Syaiful Bahri. 2002. Psikologi Belajar. Jakarta: Rineksa Cipta.
Djamarah, Syaiful Bahri. 2002. Strategi Belajar Mengajar. Jakarta: Rineksa Cipta.

Hadi, Sutrisno. 1982. Metodologi Research, Jilid 1. Yogyakarta: YP. Fak. Psikologi UGM.

Hamalik, Oemar. 2002. Psikologi Belajar dan Mengajar. Bandung: Sinar Baru Algesindo.

Margono. 1997. Metodologi Penelitian Pendidikan. Jakarta. Rineksa Cipta.

Munir, Emha Syamsul. 1983. "Mengenal Teater". Dalam Majalah Sahabat Pena, No. 143. Jakarta.

Nio, Bo Kim Hoa. 1981. Pengajaran Apresiasi Drama. Jakarta: Penataran

Nur, Moh. 2001. Pemotivasian Siswa untuk Belajar. Surabaya: University Press. Univesitas Negeri Surabaya.

Rustiyah, N.K. 1991. Strategi Belajar Mengajar. Jakarta: Bina Aksara.

Sardiman, A.M. 1996. Interaksi dan Motivasi Belajar Mengajar. Jakarta: Bina Aksara.

Sukidin, dkk. 2002. Manajemen Penelitian Tindakan Kelas. Surabaya: Insan 
Reforma: Jurnal Pendidikan dan Pembelajaran Vol. 8 No. 2 (2019) p-ISSN: 2503-1228; e-ISSN: 2621-4172

Cendekia.

Syah, Muhibbin. 1995. Psikologi Pendidikan, Suatu Pendekatan Baru. Bandung: Remaja Rosdakarya.

Syam, Syahlinar. 1984. Bina Drama. Bandung: Jurusan Sendra Tasik FPBS IKIP
Udin, Syahlinar. 1982. Rencana dan Pelaksanaan Pengajaran Seni Drama. Padang: Jurusan Sendratasik FPBS IKIP Padang.

Usman, Moh. Uzer. 2001. Menjadi Guru Profesional. Bandung: Remaja Rosdakarya. 